\title{
Physico-Chemical Diversity Analysis in Lime [C. aurantiifolia (Christm.) Swingle], Lemon (C. limon Burm. f.) and Hill Lemon (C. pseudolimon Tan.) Species Collected from the Foothills of Himalaya, India
}

\author{
Nemappa Lambani ${ }^{*}$, S.K. Malik ${ }^{2}$, Sukhdeep Kaur ${ }^{2}$, Ravish Choudhary ${ }^{1}$, \\ M.R. Rohini ${ }^{1}$, K.V. Bhat $^{2}$ and Rekha Chaudhury ${ }^{2}$ \\ ${ }^{1}$ Indian Agricultural Research Institute, Pusa Campus, New Delhi, India \\ ${ }^{2}$ Tissue Culture and Cryopreservation Unit, National Bureau of Plant Genetic Resources \\ (NBPGR), Pusa Campus, New Delhi 110 012, India \\ *Corresponding author
}

\section{A B S T R A C T}

\begin{tabular}{l} 
K e y w or d s \\
Lime, Lemon, Pseudo \\
limon, PCA, UPGMA, \\
Physicochemical, \\
Diversity, Scatter plot \\
\hline Article Info \\
$\begin{array}{l}\text { Accepted: } \\
\text { 26 December } 2017 \\
\text { Available Online: } \\
\text { 10 January } 2018\end{array}$ \\
\hline
\end{tabular}

Keywords

Lime, Lemon, Pseudo CA, UPGMA Diversity, Scatter plot

\section{Introduction}

India is abode of vast Citrus diversity and is considered as one of the centers of origin along with other south Asian countries and Australia. Lime [Citrus aurantiifolia (Christm.) Swingle] and Lemon (Citrus limon Burm. f.) are the important Citrus crops grown on third largest area (Approximate 2.45 lakh ha), and rank second in production (Approximate $2.43 \mathrm{mt}$ ) among all the fruit crops of India (NHB, 2015). Citrus pseudo

\begin{abstract}
Forty two Physico-chemical characters recorded from 32 accessions of Lime, Lemon and Pseudo limon accessions collected from four districts of Himachal Pradesh in India were subjected to diversity studies. Descriptive statistics showed vast variation in Fruit size, Fruit rind thickness, petiole wing width and numbers of seeds / fruit. PCA showed a total of 30 components of which first ten accounted for $87.24 \%$ of variability. Jaccard's similarity matrix showed highest similarity value of 0.59 , the least similarity value of 0.1 and the average similarity of all 32 accessions were 0.31 . The UPGMA tree obtained by Jaccard's similarity matrix divided all 32 accessions in to three major species specific clusters with few acceptions. Mantel test $(r=0.28)$ showed positive linear correlation between UPGMA tree and the distance matrix. 2D and 3D scatter plots were in support of the UPGMA clustering pattern.
\end{abstract}

limon (Hill lemon) is an indigenous species of lemon restricted to the foothills of Himalayan states in India. Lime has numerous medicinal properties such as astringent, tonic, antiscorbutic, antiseptic, diuretic and also used for curing rheumatism and arthritis (Wealth of India, 1992), whereas Lemon has antibacterial, antifungal, antiviral, anti-diabetic and anticancerous properties (Duthie and Crozier, 2000, Kawaii et al., 2000, Burt, 2004; Ortuno et al., 2006, Kurutas et al., 2016). All edible Citrus fruit species under subgenus 
Eucitrusare classified in to five horticulture groups among which lime and lemon are grouped in to Acid group (Hodgson, 1965; Malik et al., 2012; Naik et al., 2014). Citrus aurantiifolia (Christm.) Swingle, (Rutaceae) $(2 \mathrm{n}=18)$ commonly known as Sour/Acid Lime hasvarious vernacular names as Nimbu, Limbu, Nimba, Kagzi lime, Atolnimbu and Arunachal lime (Malik et al., 2012). Lime is believed to have its origin in Southeastern Asia including parts of east and north-eastern India, northern Burma, southwest China and eastward to the Malay Archipelago (Moore, 2001; Nair and Nayar., 1997). Arabs carried Lime across North Africa into Spain and Portugal and It was taken to the America by Spanish and Portuguese explorers during sixteenth century (Ziegler and Wolfe, 1961). Lime is hypothesized to be of tri-hybrid origin (a three-way hybrid between three different Citrus species) of Pummelo (Citrus grandis), Citron (Citrus medica), and a micro citrus species named Citrus micrantha (Barrett and Rhodes 1976, Curk et al., 2016). Citrus limon Burm. f. $(2 \mathrm{n}=18)$ is commonly known as Lemon and has different vernacular names such as Nimbu, Assam lemon, Kagjikalan, Baramasi lemon (Dass et al., 1976; Malik et $a l ., 2012)$. It is distributed throughout India. Lemon has a mystical origin; it is hypothesized to be initially grown in south India, North Burma and china. Studies indicate that Lemon is a natural hybrid of sour orange and Citron parents. C. pseudo limon Tan. $(2 \mathrm{n}=18)$ also called as Hill lemon or Galgal is considered to be an indigenous species of Citrus which is morphologically distinct from Lemon. Due to its morphological variation and growing habitat Hill lemon is considered to be a separate species, which is mainly growing in north India especially in the foothills of lower Himalayas. This species is widely adapted, having high yield potential, tolerance to citrus canker and hardy to both hot and cold climatic conditions (Singh, 1992).
Only miniscule amount of the available vast natural Citrus diversity, in wild and semi-wild form are utilized for crop improvement programs in India. Lack of proper characterization limits the importance and use of germplasm. So, characterization is a basic requirement to assess the existing diversity of the Citrus germplasm for its utilization inbreeding program. India being one of the centers of origin for Citrus has a great responsibility to document, preserve and transfer this natural gift of vast diversity to the future generations. This study is an effort in that direction to describe and document the existing physico-chemical diversity among Lime, Lemon and Hill lemon species.

\section{Materials and Methods}

\section{Plant material}

Thirty two accessions representing $C$. aurantiifolia, $C$. limon and $C$. pseudolimon were collected in the form of fruits and leaves from the districts of Bilaspur, Mandi, Hamirpur and Shimla in Himachal Pradesh of India (Table 1). Collections were mostly made following selective sampling strategy, where samples collected from single plant was given an indigenous collection number (IC number) and treated as individual accession. Leaf and fruit samples of each accession were taken for confirmation of taxonomic identity and morphological characterization. The fruits were cut open and seeds were extracted by peeling off the transparent membrane of closely packed carpel segments and mucilage was removed by washing in warm water for documenting seed related traits.

\section{Physical characterization}

Physical characterization was carried out by documenting Quantitative and qualitative traits of fruit, leaf and seed of three citrus species as per the IPGRI (International Plant 
Genetic Resources Institute presently known as Bioversity International) Citrus descriptor.

\section{Chemical characterization}

Chemical characterization of citrus was done by measuring $\mathrm{pH}$ of the filtered Citrus juice by using PH meter. Total soluble solids (TSS or Brix) of the fresh juice were determined by using Brix meter. For measuring Total titrable acidity (TA), the fruits were brought to room temperature and juice was extracted by pressing the cut fruit with hand press and filtered by using muslin cloth. 6 grams of fruit juice was weighed in $100 \mathrm{ml}$ beaker and titrated with $0.1 \mathrm{~N} \mathrm{NaOH}$ to an end point of 8.2 by phenolphthalein indicator and reading on burette indicating milliliters (mls) of $\mathrm{NaOH}$ used was recorded. Titrable acidity was calculated using 0.064 as milli equivalent factor in the following formula. Because the milli equivalent factor of Citric Acid is 0.064 which is a prominent acid of Citrus juice (Crisosto et al., 1997).

$\%$ acid $=\frac{[\mathrm{mls} \mathrm{NaOH} \mathrm{used}] \times[0.1 \mathrm{~N} \mathrm{NaOH}] \times[\text { milliequivalent factor }] \times[100]}{\text { grams of sample }}$

\section{Physico-chemical data analysis}

Descriptive statistics were calculated by pooling all the quantitative data of three species together by using SPSS software (Table 2). Further all the Forty two discrete morphological traits including 14 quantitative and 28 qualitative characters documented as per the IPGRI Citrus descriptor were converted into bistates and multi states (interval) code. Standardization of morphological data was carried out by using YBAR option in the NTSYS ver. 2.10e software (Rohlf, 2000). Further a pairwise similarity matrix was also generated using Simple Matching coefficient and Neighbour Joining dendrogram was built based on Euclidean distance. 2D and3D scatter plots were obtained using Principal Component
Analysis (PCA) data through Eigen option under Ordination head of the NTSYS software.

\section{Results and Discussion}

Descriptive statistics values of morphological data showed vast variation among collection. The five characters which recorded highest variation were Fruit size, Fruit rind thickness, petiole wing width and numbers of seeds / fruit, these traits are of great value for the Citrus breeding program. The principle component analyasis (PCA) of multivariable physicochemical data showed formation of a total of 30 principal components, out of which first ten principal components contributed $87.24 \%$ of the total variability. The first five principal components accounted for $68.12 \%$ of the total variation and the first three for $55.75 \%$ of the variation, in which maximum variation was contributed by the first component $(27.25 \%)$ followed by the second component (19.24\%), and third component $(9.21 \%)$. The first PC was highly influenced by characteristics of the fruit morphology viz., fruit weight, fruit diameter, Fruit length, Width of epicarp at equatorial area, Fruit rind thickness. The second PC was more influenced by the seed elated traits like seed shape, color of cotyledons, and spot color of chalaza and seed embryo. The third PC was ruled by leaf related characteristics like, leaf lamina attachment, presence or absence of petiole wings and petiole wing shape

Jaccard's similarity matrix captured this variation with value range of 0 to 1,0 being no similarity (meaning highest diversity) and 1being cent percent similarity (meaning no diversity). Lemon accessions $\mathrm{N}-26$ and N-32 along with $\mathrm{N}-27$ and N-31 showed highest Jaccard's similarity (0.59) among themselves, whereas Lemon accession N-32 and Lime accession N-39 (0.1) showed least similarity value between them. 
Table.1 List of Lime, Lemon and Pseudo limon accessions used for Physico-chemical analysis

\begin{tabular}{|c|c|c|c|c|c|c|c|c|}
\hline \multirow[t]{2}{*}{ SI } & $\begin{array}{l}\text { Collection } \\
\text { no. }\end{array}$ & $\begin{array}{l}\text { Botanical } \\
\text { name }\end{array}$ & Source of collection & Lat & Longit & $\begin{array}{c}\text { IC } \\
\text { number }\end{array}$ & Status & Frequency \\
\hline & & C. aurantiifolia & & & & & & \\
\hline 1 & N-5 & & SadarBlock, Bilaspur, HP & 32.41 & 76.43 & $\begin{array}{c}\text { IC- } \\
395356\end{array}$ & Cultivated & Frequent \\
\hline 2 & $\mathrm{~N}-10$ & & Musavarmod, Gumarami, Bilaspur, HP & 31.30 & 76.43 & $\begin{array}{c}\text { IC- } \\
438459\end{array}$ & Cultivated & Frequent \\
\hline 3 & $\mathrm{~N}-15$ & & Baggi,Gopalpur,Sarkaghat, Mandi, HP & 31.36 & 76.43 & $\begin{array}{c}\text { IC- } \\
260354\end{array}$ & Cultivated & Frequent \\
\hline 4 & N-17 & & Baggi,Gopalpur,Sarkaghat, Mandi, HP & 31.36 & 76.43 & $\begin{array}{l}\text { IC- } \\
470330\end{array}$ & Cultivated & Frequent \\
\hline 5 & $\mathrm{~N}-22$ & & Baggi,Gopalpur,Sarkaghat, Mandi, HP & 31.36 & 76.43 & $\begin{array}{c}\text { IC- } \\
537670\end{array}$ & Cultivated & Frequent \\
\hline 6 & $\mathrm{~N}-23$ & & Gehari, Gopalpur, SarkaghatMandi, HP & 31.36 & 76.43 & $\begin{array}{l}\text { IC- } \\
611558\end{array}$ & Cultivated & Frequent \\
\hline 7 & $\mathrm{~N}-30$ & & Navasi, Sarkaghat, Mandi, HP & 31.40 & 76.44 & $\begin{array}{l}\text { IC- } \\
611559\end{array}$ & Cultivated & Frequent \\
\hline 8 & $\mathrm{~N}-34$ & & Tikrikurala, Bhoranj, Hamirpur, HP & 31.38 & 76.39 & $\begin{array}{l}\text { IC- } \\
593850\end{array}$ & Cultivated & Frequent \\
\hline 9 & N-39 & & Dehra, Gumarami, Bilaspur, HP & 31.34 & 76.42 & $\begin{array}{l}\text { IC- } \\
611560\end{array}$ & Cultivated & Frequent \\
\hline \multirow[t]{2}{*}{10} & $\mathrm{~N}-41$ & & Dudhal, Gumarami, Bilaspur, HP & 31.29 & 76.39 & -- & Cultivated & Frequent \\
\hline & & C. limon & & & & & & \\
\hline 11 & $\mathrm{~N}-12$ & & Manua, Gumarami, Bilaspur, HP & 31.31 & 76.44 & $\begin{array}{l}\text { IC- } \\
415175\end{array}$ & Cultivated & Frequent \\
\hline 12 & $\mathrm{~N}-25$ & & Talav, Gopalpur, Sarkaghat, Mandi, HP & 31.38 & 76.43 & -- & Cultivated & Frequent \\
\hline 13 & $\mathrm{~N}-26$ & & Nalta,Gopalpur, Sarkaghat,Mandi, HP & 31.38 & 76.43 & -- & Cultivated & Frequent \\
\hline 14 & $\mathrm{~N}-27$ & & Behna, Gopalpur, Sarkaghat, Mandi, HP & 31.38 & 76.43 & -- & Cultivated & Frequent \\
\hline 15 & N-31 & & Navasi, Sarkaghat, Mandi, HP & 31.40 & 76.44 & -- & Cultivated & Frequent \\
\hline 16 & $\mathrm{~N}-32$ & & Tatahar, Sarkaghat, Mandi, HP & 31.40 & 76.43 & -- & Cultivated & Frequent \\
\hline 17 & $\mathrm{~N}-33$ & & Tatahar, Sarkaghat, Mandi, HP & 31.40 & 76.43 & - & Cultivated & Frequent \\
\hline 18 & $\mathrm{~N}-35$ & & Lag, Bhoraj, Hamirpur, HP & 31.37 & 76.40 & -- & Cultivated & Frequent \\
\hline \multirow[t]{2}{*}{19} & N-36 & & Lag, Bhoranj, Hamirpur, HP & 31.37 & 76.40 & $\begin{array}{c}\text { IC- } \\
395354\end{array}$ & Cultivated & Frequent \\
\hline & & C. Pseudolimon & & & & & & \\
\hline 20 & N-1 & & Jukhala, Bilaspur, HP & 32.36 & 76.41 & $\begin{array}{l}\text { IC- } \\
395349\end{array}$ & Cultivated & Abundant \\
\hline 21 & $\mathrm{~N}-11$ & & Musarvarmod, Gumarami, Bilaspur, HP & 31.30 & 76.43 & $\begin{array}{l}\text { IC- } \\
395350\end{array}$ & Cultivated & Abundant \\
\hline 22 & N-14 & & Manua, Gumarani, Bilaspur, HP & 31.31 & 76.44 & $\begin{array}{c}\text { IC- } \\
395352\end{array}$ & Cultivated & Abundant \\
\hline 23 & $\mathrm{~N}-18$ & & Baggi, Gopalpur, Sarkaghat, Mandi, HP & 31.36 & 76.43 & $\begin{array}{c}\text { IC- } \\
395375\end{array}$ & Cultivated & Abundant \\
\hline 24 & $\mathrm{~N}-19$ & & Baggi, Gopalpur, Sarkaghat, Mandi, HP & 31.36 & 76.43 & $\begin{array}{l}\text { IC- } \\
395355\end{array}$ & Cultivated & Abundant \\
\hline 25 & $\mathrm{~N}-21$ & & Baggi, Gopalpur, Sarkaghat, Mandi, HP & 31.36 & 76.43 & $\begin{array}{c}\text { IC- } \\
593851\end{array}$ & Cultivated & Abundant \\
\hline 26 & $\mathrm{~N}-24$ & & $\begin{array}{l}\text { Gehari, Gopalpur, Sarkaghat, Mandi, } \\
\text { HP }\end{array}$ & 31.36 & 76.43 & $\begin{array}{c}\text { IC- } \\
365364\end{array}$ & Cultivated & Abundant \\
\hline 27 & $\mathrm{~N}-29$ & & Navasi, Sarkaghat, Mandi,HP & 31.40 & 76.44 & $\begin{array}{c}\text { IC- } \\
470331\end{array}$ & Cultivated & Abundant \\
\hline 28 & N-37 & & Lag, Bhoranj, Hamirpur, HP & 31.37 & 76.40 & $\begin{array}{c}\text { IC- } \\
395355\end{array}$ & Cultivated & Abundant \\
\hline 29 & $\mathrm{~N}-28$ & & Tamaro, Bhoranj, Hamirpur, HP & 31.35 & 76.39 & $\begin{array}{c}\text { IC- } \\
395357\end{array}$ & Cultivated & Abundant \\
\hline 30 & $\mathrm{~N}-40$ & & Ledhyani, gumarami, Bilaspur, HP & 31.32 & 76.39 & $\begin{array}{c}\text { IC- } \\
395359\end{array}$ & Cultivated & Abundant \\
\hline 31 & $\mathrm{~N}-42$ & & Phagli, Shimla, HP & 31.05 & 77.09 & $\begin{array}{c}\text { IC- } \\
395361\end{array}$ & Cultivated & Abundant \\
\hline 32 & $\mathrm{~N}-43$ & & Phagli, Shimla, HP & 31.05 & 77.09 & $\begin{array}{l}\text { IC- } \\
593858\end{array}$ & Cultivated & Abundant \\
\hline
\end{tabular}


Table.2 Descriptive statistics and Principal Component Analysis (PCA) of qualitative and quantitative characters of Lime, Lemon and Pseudo limon species

\begin{tabular}{|c|c|c|c|c|c|c|c|}
\hline Sl.No. & Trait & Mean & $\mathrm{SD}$ & Range & $\mathrm{PC} 1$ & $\mathrm{PC} 2$ & PC3 \\
\hline 1 & Fruit weight (g) & 176.69 & 154.27 & $\begin{array}{l}21.67- \\
513.33\end{array}$ & 0.892 & 0.208 & 0.022 \\
\hline 2 & Fruit diameter(cm) & 59.90 & 20.79 & $\begin{array}{c}31.43- \\
94.51\end{array}$ & 0.904 & 0.085 & -0.042 \\
\hline 3 & Fruit length $(\mathrm{cm})$ & 74.13 & 30.31 & $\begin{array}{l}36.53- \\
130.01\end{array}$ & 0.926 & 0.134 & -0.003 \\
\hline 4 & Width of epicarp at equatorial area (mm) & 1.29 & 0.58 & $0.55-2.36$ & 0.849 & 0.048 & 0.155 \\
\hline 5 & Fruit rind thickness $(\mathrm{cm})$ & 3.98 & 2.26 & $1.01-9.38$ & 0.904 & 0.081 & 0.036 \\
\hline 6 & No of segments per fruit & 10.89 & 1.30 & $9-14$ & -0.062 & -0.653 & -0.057 \\
\hline 7 & No of seed/fruit & 12.41 & 9.20 & $0-30$ & 0.571 & 0.690 & -0.175 \\
\hline 8 & 10 seed wt. $(\mathrm{gm})$ & 1.13 & 0.95 & $0-2.75$ & -0.053 & -0.963 & 0.083 \\
\hline 9 & Leaf lamina length(mm) & 76.87 & 19.50 & $\begin{array}{l}46.92- \\
122.04\end{array}$ & 0.773 & -0.138 & 0.088 \\
\hline 10 & Leaf lamina width (mm) & 41.27 & 11.99 & $\begin{array}{c}26.79- \\
78.35\end{array}$ & 0.835 & -0.102 & -0.002 \\
\hline 11 & Ratio leaf lamina $1 / w$ & 1.89 & 0.24 & $1.22-2.36$ & -0.309 & -0.020 & 0.197 \\
\hline 12 & Leaf thickness (mm) & 0.14 & 0.06 & $0.05-0.36$ & 0.226 & -0.619 & -0.050 \\
\hline 13 & Petiol wing width & 1.87 & 1.58 & $0-7.36$ & -0.348 & 0.295 & 0.345 \\
\hline 14 & Titrable Acidity & 6.53 & 1.00 & $4.35-8.19$ & -0.185 & 0.355 & -0.199 \\
\hline 15 & Fruit shape & - & - & - & 0.291 & -0.199 & -0.058 \\
\hline 16 & Shape of fruit base & - & - & - & 0.164 & 0.210 & -0.091 \\
\hline 17 & Shape of fruit apex & - & - & - & -0.401 & 0.049 & 0.320 \\
\hline 18 & Fruit skin colour & - & - & - & 0.466 & 0.061 & -0.150 \\
\hline 19 & Fruit surface texture & - & - & - & 0.315 & -0.052 & 0.150 \\
\hline 20 & Adherence of albedo to pulp & - & - & - & -0.558 & -0.209 & -0.213 \\
\hline 21 & Nature of oil glands & - & - & - & -0.099 & -0.124 & -0.038 \\
\hline 22 & Density of oil glands on fruit surface & - & - & - & -0.152 & -0.257 & -0.055 \\
\hline 23 & Oil glands size on fruit Surface & - & - & - & 0.000 & 0.000 & 0.000 \\
\hline 24 & Pulp colour & - & - & - & 0.104 & 0.159 & 0.112 \\
\hline 25 & Pulp firmness & - & - & - & -0.555 & -0.335 & -0.316 \\
\hline 26 & Juice content in endocarp & - & - & - & 0.317 & 0.575 & -0.089 \\
\hline 27 & Taste of juice TSS & - & - & - & -0.053 & -0.212 & -0.16 \\
\hline 28 & Seed shape & - & - & - & 0.15 & 0.912 & -0.101 \\
\hline 29 & Seed surface & - & - & - & 0.014 & 0.881 & -0.006 \\
\hline 30 & Seed colour & - & - & - & -0.126 & 0.162 & 0.04 \\
\hline 31 & Colour of cotyledons & - & - & - & -0.063 & 0.632 & -0.02 \\
\hline 32 & Chalazal spot colour & - & - & - & 0.207 & 0.922 & -0.106 \\
\hline 33 & Seed embryo & - & - & - & -0.016 & 0.857 & -0.229 \\
\hline 34 & Leaf division & - & - & - & 0.000 & 0.000 & 0.000 \\
\hline 35 & Intensity of green colour of leaf blade & - & - & - & -0.069 & -0.264 & 0.038 \\
\hline 36 & Leaf colour variegation & - & - & - & 0.000 & 0.000 & 0.000 \\
\hline 37 & Leaf lamina attachment & - & - & - & 0.015 & -0.107 & 0.959 \\
\hline 38 & Leaf lamina shape & - & - & - & -0.027 & -0.073 & 0.056 \\
\hline 39 & Leaf lamina margin & - & - & - & -0.212 & 0.213 & -0.416 \\
\hline 40 & Leaf apex & - & - & - & -0.124 & -0.005 & 0.117 \\
\hline 41 & Absence/prasence of petiole wings & - & - & - & 0.015 & -0.107 & 0.959 \\
\hline 42 & Petiol wing shape & - & - & - & 0.247 & -0.425 & \\
\hline
\end{tabular}


Fig.1 UPGMA dendrogram of 32 Citrus accessions based on physico-chemical data analysis

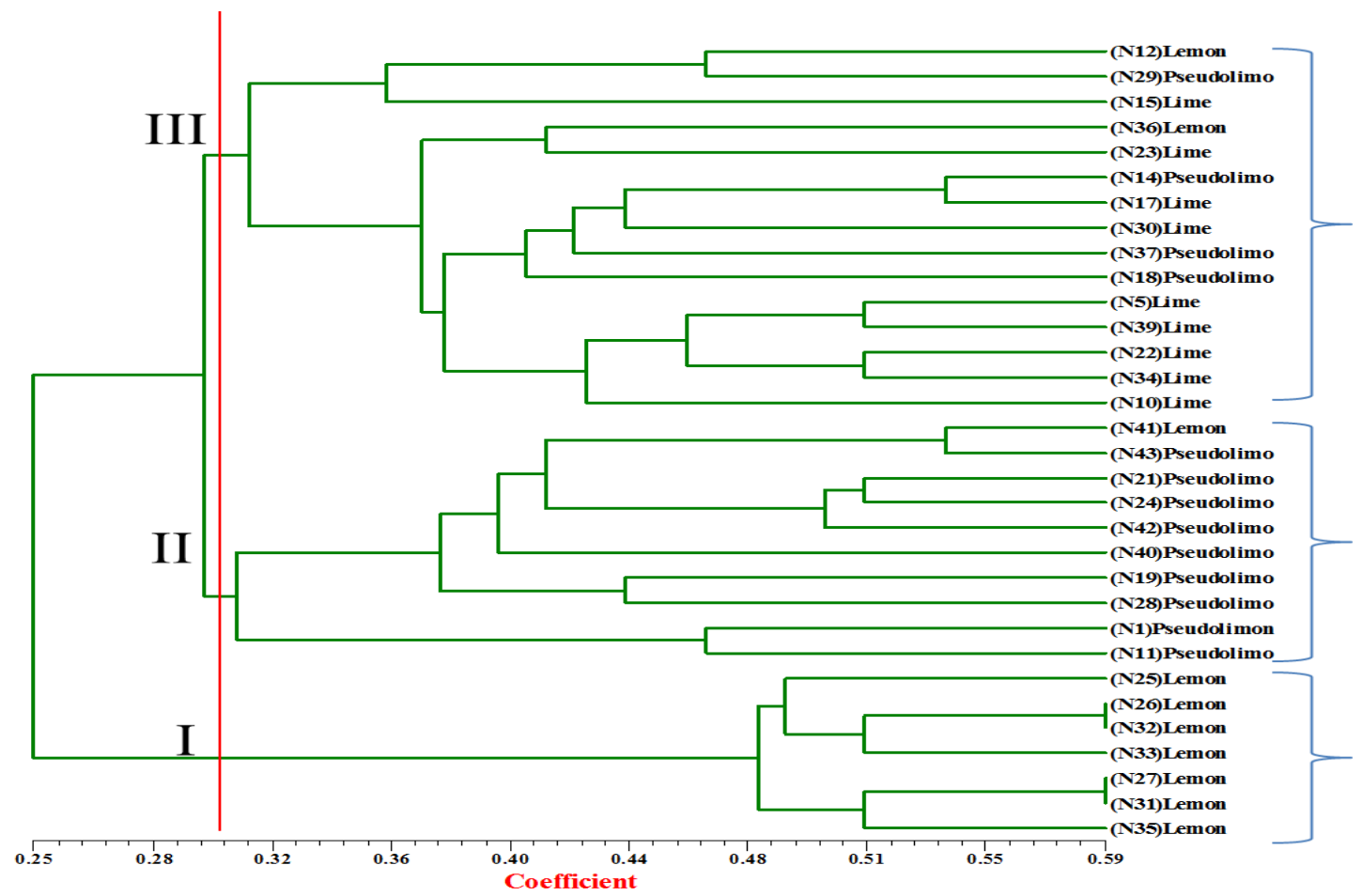

Fig.2 2D scatterplot of 32 Citrus accessions based on analysis of 42 physicochemical traits

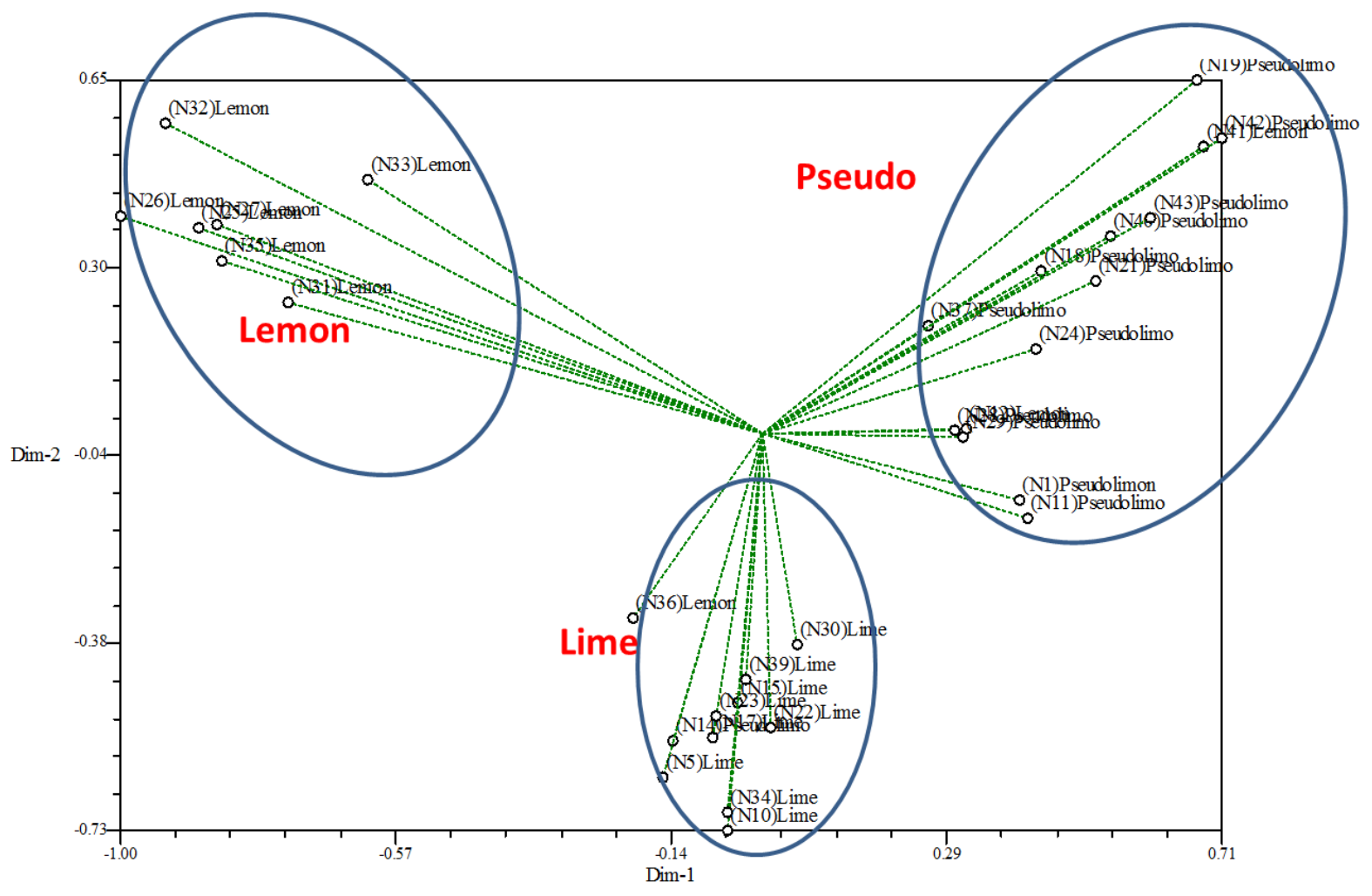


Fig.3 3D scatter plot of 32 Citrus accessions based on analysis of 42 physicochemical traits

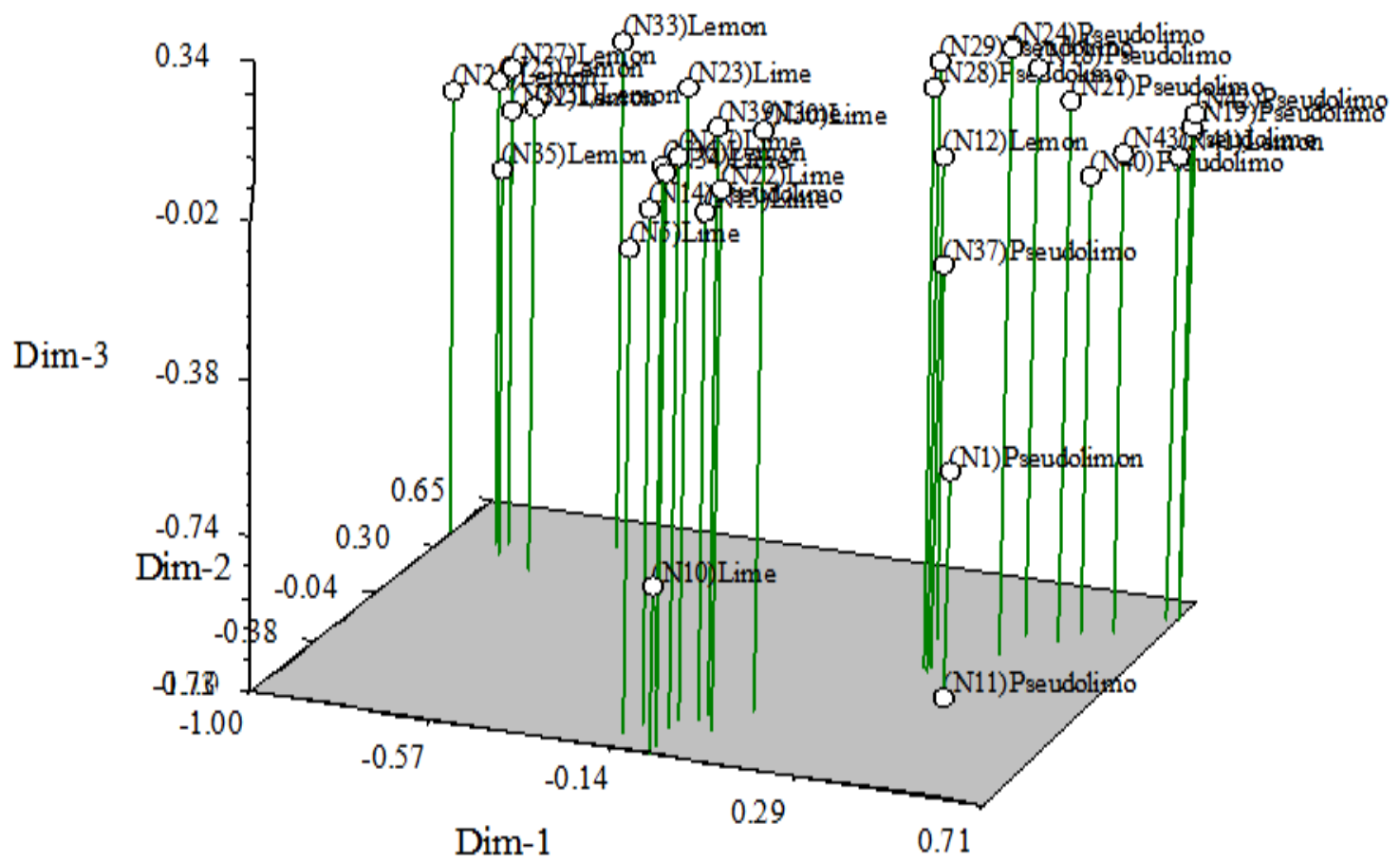

The average similarity value observed among all 32 accessions was 0.311 .

The UPGMA tree obtained by using Jaccard's similarity matrix divided all 32 accessions in to three major clusters. Cluster I and II contained Lemon and Pseudo limon accessions respectively, but cluster III showed the grouping of all the Lime accessions along with few admixture of Lemon and Pseudo limon accessions (Figure 1).

Based on Normalized Mantel Z statistics the correlation coefficient (r) was estimated at 0.28 . The value of 0.28 indicates positive linear correlation between UPGMA cluster patterns to the data. A two dimensional (2-D) plot (Figure 2) and a three dimensional (3-D) plot (Figure 3) generated from matrix comparison plot under graphics in NTSYS showed three major groups which were found to be similar and supporting to the clustering pattern of the UPGMA dendrogram. In conclusion this study collected, characterized and submitted germplasms of significant diversity of Lime, Lemon and Pseudo limon species to the National gene bank which acts as a treasure in reserve for future Citrus breeding programs.

\section{Acknowledgement}

I gratefully acknowledge the funding received from ICAR towards my $1^{\text {st }}$ Year and from UGC-CSIR for subsequent years of PhD. I also acknowledge post-graduate school, IARI, New Delhi for providing me the opportunity to perceive my Ph.D.

\section{References}

Burt, S.A., 2004. Essential oils: Their antibacterial properties and potential applications in foods: A review. Inter. J. Food Microbiol, 94: 223-253.

Crisosto, C.H., D. Garner, G.H. Crisosto, P. 
Wiley, and S. Southwick. 1997. Evaluation of the minimum maturity index for new cherry cultivars growing in the San Joaquin Valley. Calif. Cherry Growers Assn., Visalia.

Dass, H. C, G. S. Randhawa and D. Prakash 1976. Chemosystematic Studies in Relation to Variability in Citrus limon; Indian Journal of Experimental Biology Vol. 15, No.2, February 1977, pp 158160; Indian Institute of Horticultural Research, Bangalore-560006; 10 August 1976

Duthie, G.; Crozier, A. Plant-derived phenolic antioxidants. Curr.Opin.Lipidol. 2000, 11, 43-47.

Hodgson, R.W., 1965. Taxonomy and nomenclature in citrus fruits. In: Advances in Agricultural Science and Their Application. Madras Agric. J. pp. 317-331.

Kawaii, S., T. Yasuhiko, K. Eriko, O. Kazunori, Y. Masamichi, K. Meisaku, ChihiroIto and F. Hiroshi, 2000. Quantitative study of flavonoids in leaves of Citrus plants J. Agric. Food Chem., 48: 3865-3871.

Kurutas, E. B., 2016. The importance of antioxidants which play the role in cellular response against oxidative/ nitrosative stress: current state. Nutrition Journal, 15, 71.

Malik, S.K., Chaudhury R., Kumar S., Dhariwal O.P., and Bhandari D.C., 2012. Citrus Genetic Resources in
India: Present Status and Management. National Bureau of Plant Genetic Resources, New Delhi, India, p. 184.

Moore, G.A. 2001. Oranges and lemons: clues to the taxonomy of Citrus from molecular markers. Trends in Genetics 17: 536-540.

Naik B. H., and Thippesh D., 2014. Fundamentals of Horticulture and Production technology of fruit crops: econtents of course material; University of Agricultural and Horticultural Sciences, Shimoga

Nair K. N., and Nayar M. P. 1997. Rutaceae Pp. 229-407 In: Hajra P. K., editor;, Nair V. J., editor;, Daniel P., editor., eds. Flora of India. Vol. IV. Botanical Survey of India, Calcutta, India.

Ortuno, A.A., P. Baidez, M.C. Gomez, I. Arcas, A.G. Porras and J.A. Del Rio, 2006. Citrus paradise and Citrus sinensis flavonoids: Their influence in the defence mechanism against Penicillium digitatum. Food Chem., 98(2): 351-358.

Rohlf, F.J. 2000. NTSYS-pc: Numerical Taxonomy and Multivariate Analysis System Version 2.1. Exeter Publishing Setauket, New York

Singh, R. 1992. Fruits. National Book Trust, New Delhi, India

Ziegler, L.W. and H.S. Wolfe. 1961. Citrus growing in Florida. University of Florida Press, Gainesville. 248 pp.

\section{How to cite this article:}

Nemappa Lambani, S.K. Malik, Sukhdeep Kaur, Ravish Choudhary, M.R. Rohini, K.V. Bhat and Rekha Chaudhury. 2018. Physico-Chemical Diversity Analysis in Lime [C. aurantiifolia (Christm.) Swingle], Lemon (C. limon Burm. f.) and Hill Lemon (C. pseudolimon Tan.) Species Collected from the Foothills of Himalaya, India. Int.J.Curr.Microbiol.App.Sci. 7(01): 3220-3227. doi: https://doi.org/10.20546/ijcmas.2018.701.385 